\title{
Theoretical estimation of fatigue life under regular cyclic loading
}

\author{
Oleh Herasymchuk ${ }^{1} \bullet$ Olena Herasymchuk $^{2}$ \\ 1 - G.S. Pisarenko Institute for Problems of Strength, National Academy of Sciences of Ukraine, Kyiv, Ukraine; \\ 2 - Igor Sikorsky Kyiv Polytechnic Institute, Kyiv, Ukraine
}

Received: 20 March 2017 / Accepted: 12 April 2017

\begin{abstract}
A model is proposed for the fatigue life estimation of the material with consideration of microstructure, stress concentration and cyclic load ratio. In the fatigue life estimation, the factors, such as grain size, stress concentration and cyclic load ratio are taken into account in the parameter representing the fatigue limit. In order to fill the model, it is sufficient to have results from monotonic tensile testing and characteristics of microstructure of the initial material. The model is tested using the fatigue testing results for specimens of Ti-6Al-4V titanium alloy condensate prepared by electron-beam physical vapor deposition method (EB PVD-method). The specimens had manufacturing defects, such as column defects of different diameters reaching the specimen surface. The model is also tested using the experimental fatigue data for the Ti-6Al-4V titanium alloy taken from the literature for various cyclic load ratios. Comparison between results of calculation and experiment showed a good agreement. The approach proposed can be used for the rapid assessment of fatigue resistance characteristics in new materials development, and also for the remaining life evaluation of structures with no costly and long-term fatigue and fatigue crack growth resistance tests.
\end{abstract}

Keywords: fatigue life; stress concentration; cyclic load ratio; high-cycle fatigue; microstructure; titanium alloys

Introduction. Until recently, a strong opinion existed within the scientific community studying material fatigue problems that it is not possible to calculate the fatigue life or $S-N$ curve of material without performing the fatigue or fatigue crack growth resistance testing. However, in recent years, this opinion is gradually changing due to the introduction of microstructure parameters into the fatigue process description. At present, it is generally agreed that the high-cycle fatigue (HCF) process is divided in two stages: crack nucleation stage and crack growth stage. It was proposed in [1] to estimate the life (the number of load cycles) to failure, $N_{\text {total }}$, as the sum of two lives: the life to fatigue crack initiation, $N_{i}$, and the life during fatigue crack growth, $N_{F C G}$ :

$$
N_{\text {total }}=N_{i}+N_{F C G}
$$

To evaluate the fatigue life to the initiation of a microstructurally short crack (MSC) of depth equal to one grain size, $d$, in smooth specimens of titanium alloys subjected to regular cyclic symmetrical uniaxial loading, the following equation was obtained [1]:

$$
N_{i}=\left(\frac{\beta}{\sigma_{a}-\sigma_{-1}}\right)^{2}
$$

where

$$
\beta=\frac{E M}{(1+v)^{3} \sqrt{\pi(1-v)}},
$$

where $M$ is the mean Taylor factor relative to the direction of $\sigma_{a}$, which is determined from the texture analysis of the initial material, $E$ is the elastic modulus and $v$ is Poisson's ratio, both determined from the monotonic tensile test data, $\sigma_{-1}$ is the fatigue limit for a fully-reversed loading cycle (the parameter to be calculated), $\sigma_{a}$ is the applied stress amplitude, $N_{i}$ is the number of load cycles.

The fatigue limit can be evaluated using the phenomenological formula for $\sigma_{-1}$ as a function of the grain size $d$ proposed by Herasymchuk in [2]: 


$$
\begin{gathered}
\sigma_{-1}=\frac{E \sqrt{b}}{\sqrt{l_{c}}} \\
l_{c}=E^{2} b\left(A+B \cdot \operatorname{arctg}\left(\left(E \sqrt{\frac{b}{4 d}}-A\right) / B\right)\right)^{-2},
\end{gathered}
$$

where $A=\left(\sigma_{f}+\sigma_{p}\right) / 2, B=\left(\sigma_{p}-\sigma_{f}\right) / \pi, \sigma_{f}$ is the internal friction stress in the lattice, $\sigma_{f} \cong M E(2(1+v))^{-1} \cdot 10^{-3}$, $\sigma_{p}$ is the proportionality limit, $b$ is the Burgers vector module.

The fatigue life at the second stage of fatigue failure, $N_{F C G}$, i.e., during fatigue crack growth from the initial depth $l=d$ to its final depth $l=l_{t}$, is calculated as follows [1]:

$$
N_{F C G}=\frac{1}{b}\left[\int_{d}^{l_{i}}\left(\frac{2 K_{t h, l}}{\sigma_{a}\left(Y_{1}+Y_{2}\right) \sqrt{\pi l}}\right)^{m_{l}} d l+\left(\frac{K_{t h}}{K_{T}}\right)^{m} \int_{l_{i}}^{l_{i}^{\prime}}\left(\frac{K_{T}}{\sigma_{a} Y_{2} \sqrt{\pi l}}\right)^{m_{1}} d l+\int_{l_{i}^{\prime}}^{l_{t}}\left(\frac{K_{t h}}{\sigma_{a} Y_{2} \sqrt{\pi l}}\right)^{m} d l\right],
$$

where

$$
\begin{gathered}
l_{i}=l_{s}\left(\frac{\sigma_{-1}}{\sigma_{a}}\right)^{2}, \\
l_{s}=\frac{8^{2} \cdot \pi(1+v)^{2} h}{12 \cdot M^{2} b} \cdot d, \\
\Delta K_{t h, l}=\Delta K_{t h, d} \frac{Y_{2}}{Y_{1}}\left(\frac{l}{d}\right)^{m^{\prime}}, \\
m^{\prime}=\frac{1}{2} \cdot \log \left(\frac{l_{s}}{d}\right) / \log \left(\frac{l_{s} \cdot \sigma_{-1}^{2}}{d \cdot \sigma_{a}^{2}}\right), \\
K_{t h, d}=\sigma_{-1} Y_{1} \sqrt{\pi d}, \\
m_{l}=3 \frac{\log (E \sqrt{b})-\log K_{f}}{\log K_{t h, l}-\log K_{f}}, \\
\log K_{f}=\frac{1}{3}(3 \log E+\log \sqrt{b}-5), \\
K_{t h}=\sigma_{-1} Y_{2} \sqrt{\pi l_{s}}, \\
K_{T}=\sigma_{p} \sqrt{12 \cdot \pi d}, \\
m_{1}=\left(\frac{\sigma_{a}}{\left.m_{d}^{\prime} \cdot \log \frac{\sigma_{p}}{\sigma_{-1}}\right)_{a}}, \log \frac{K_{T}}{K_{t h}}\right) / \log \sqrt{\frac{d}{l_{i}^{\prime}}},
\end{gathered}
$$

$m$ is calculated by formula (12) where $K_{t h}$ (the threshold SIF for a long crack (LC)) is substituted for $K_{t h, l}$ (the threshold SIF for a physically small crack (PSC)); $m_{d}^{\prime}$ is calculated by formula (12) where $K_{t h, d}^{\prime}$ (the threshold SIF for a MSC) is substituted for $K_{t h, l}, K_{t h, d}^{\prime}$ is calculated by formula (11) where $Y_{2}$ is substituted for $Y_{1} ; l_{t}$ is the final crack depth that is adopted as a fatigue failure criterion; $h$ is the distance between neighboring parallel slip planes in the lattice, depending on which slip system is activated relative to the mean Taylor factor $M$; $Y_{1}$ and $Y_{2}$ are the geometrical factors for the deepest point on the front of a semi-circular surface plane crack: $Y_{2}=0.73$ (for a LC and PSC), $Y_{1}$ (for a MSC) depending on $M$ is calculated by formula [3]:

$$
Y_{1}=Y_{2}\left(2 \sqrt{1 /\left(d / l_{s}+1\right)}-1\right)
$$

Equation (6) representing the sum of the lives during the crack growth in three phases is obtained by the integration of the corresponding equations for growth rate in each phase. During the first phase, lasting from depth $l$ equal to the grain size $d$ to depth $l_{i}$ determined by equation (7), the PSC grows along the slip bands in each grain. At 
this depth, $l_{i}$, the mechanism of further PSC growth is changed, and the second phase begins when the PSC is propagated in a plane perpendicular to the direction of the applied tensile stress $\sigma_{a}$ down to depth $l_{i}^{\prime}$ determined by equation (17). The crack of such size, $l_{i}^{\prime}$, can be already considered as a long crack on the assumption that the cyclic plastic zone size ahead of the crack tip reaches the grain size, $d$, and applied SIF reaches the value of $K_{T}$ (equation (15)), and the third phase, the growth of the LC down to its final depth, $l_{t}$, is started. A detailed description of the crack growth rate equations for these phases of the fatigue crack growth is presented in [3].

The validity of the above fatigue life model was verified using the results of simple bending fatigue tests for smooth specimens of different two-phase titanium alloys with three different types of microstructure. The calculation of $S-N$ curves showed satisfactory agreement with the experimental results [1].

The purpose of this paper is to apply the above-mentioned approach to the case where a fatigue crack emanates and grows from the notch tip, and also in the presence of the cycle asymmetry, which, as a rule, takes place in structures operating under alternating load conditions.

Stress concentration. It is seen from expression (3) that the coefficient $\beta$ from (2) is determined in terms of the elasticity parameters $E$ and $v$, and texture parameter $M$, with $\sigma_{a}$ being the amplitude of nominal applied stresses. In general case, the exponent in equation (2) differs from 2 and depends on the stacking fault energy and slip morphology. As was experimentally found by many researchers, the value of 2 is satisfactorily suited for titanium alloys and some other alloys [1]. Hence, an important conclusion follows that the factors, such as grain size and stress concentration, should be taken into account in the calculation of $N_{i}$ in terms of the parameter representing the fatigue limit. Thus, for the calculation of the fatigue life (or $S$ - $N$ curves) to crack initiation, in the presence of the above-mentioned factors, it is necessary to be able to calculate the fatigue limit with consideration of these factors.

The effect of stress concentration on the fatigue limit is usually represented by fatigue notch factor, $K_{f}$, defined by the ratio of the fatigue limit of smooth specimens, $\sigma_{-1, e}$, to the fatigue limit of notched specimens, $\sigma_{-1, K}$. In [4] Lukas and Klesnil proposed an empirical formula for determining $K_{f}$ of the following form:

$$
K_{f}=K_{t} / \sqrt{1+4.5 \cdot l_{c}^{*} / \rho},
$$

where $K_{t}$ is the elastic stress concentration factor for a notch of radius $\rho, l_{c}^{*}$ is the so-called "critical distance". This formula works well for the so-called "blunt and shallow" notches $\left(K_{t} \leq 4\right)$, especially for circular or elliptical holes. A critical distance in formula (19), $l_{c}^{*}$, is the distance from the notch tip (in the direction perpendicular to $\sigma_{a}$ ), at which the elastic local stress reaches the level $\sigma_{-1, e}$ under the action of the nominal stress $\sigma_{a}$ equal to $\sigma_{-1, K}$. In the derivation of the formula similar to that in (19), different meanings of $l_{c}^{*}$ were given by different authors, thus adjusting formula (19) for better agreement with experimental results. In general, they associated $l_{c}^{*}$ with an additional crack size, $l_{s}$, which was introduced by El Haddad [5] in order to use the approaches of linear-elastic fracture mechanics during the short crack analysis, and which was determined from equation (14) by substituting the experimentally established threshold SIF for a LC, $K_{t h}$, and the fatigue limit of smooth specimens, $\sigma_{-1}$. However, these parameters, $l_{c}^{*}$ and $l_{s}$, have a different physical meaning. Thus, $l_{c}^{*}$, along with the above mentioned meaning, represents a distance from the notch tip, at which the local stress elastic-plastic distribution curve in the vicinity of the notch tip reaches the maximum level [6]. In contrast, the parameter $l_{s}$, as was shown in [3], represents the depth of a PSC from the surface of the smooth specimen, at which the maximum level of crack closure is reached and crack growth rate reaches the minimum, and the mechanism of further crack growth is changed. In this case, the SIF at its tip reaches the threshold value for a LC, $K_{t h}$, under the action of $\sigma_{a}$ maximally close to $\sigma_{-1}$.

Analyzing the classical dependence of the fatigue limits of notched specimens on $K_{t}$ [7], which shows that for $K_{t}>4$ the fatigue limit is independent of $K_{t}$, it can be concluded that for low $K_{t}<4$, the behavior of notched specimens is similar to that of smooth ones. In other words, if in the smooth specimens at their fatigue limit, nonpropagating cracks of grain size, i.e. MSC, can appear, as is stated in [8], then, in the specimens with blunt and shallow notches at their fatigue limits, non-propagating cracks of the same size can arise. But in the specimens with deep and sharp notches, i.e., for $K_{t}>4$, non-propagating cracks of greater size, i.e. PSC, will occur at their fatigue limits due to the crack closure, and the fatigue strength becomes independent of $K_{t}$ and is determined primarily by the notch depth and threshold stress, $\sigma_{t h}$, for PSC. On this basis, it was assumed that for such low $K_{t}$, the parameters $l_{c}^{*}$ from equation 
(19) and $l_{c}$ from equation (4) are equal. Thus, in view of (4) and (19), the formula for calculating the fatigue limit of specimens with blunt and shallow notches $\left(K_{t} \leq 4\right)$ is of the following form:

$$
\sigma_{-1}=\frac{E \sqrt{b}}{K_{t}} \sqrt{1 / l_{c}+4.5 / \rho} \text {, }
$$

where $l_{c}$ is calculated by equation (5).

After the crack has been initiated at the notch tip at a stress level higher than the fatigue limit, it initially grows under stress gradient conditions until it leaves the notch-stress field. The depth of this notch-stress field, $l^{*}$, can be calculated using the below formula proposed by Dowling [9]:

$$
l^{*}=\rho /\left(K_{t}^{2}-1\right) \text {. }
$$

As was proposed by Chan [10], in the fatigue life estimation, the average stress amplitude, $\bar{\sigma}_{a}(l)$, can be used instead of the applied stress amplitude $\sigma_{a}$ for a crack growing in the notch-stress field. It is calculated by the following simplified formula:

$$
\bar{\sigma}_{a}(l)=K_{t} \cdot \sigma_{a} \cdot(1-l / \rho) .
$$

Thus, the fatigue life during the crack growth emanating from the notch tip will be calculated by the same equation (6), but one of three growth segments will be divided in two parts depending on the distance $l^{*}$ with respect to the characteristic segment sizes, $l_{i}$ and $l_{i}^{\prime}$.

To confirm the validity of the above-proposed model for calculating the fatigue life of specimens with surface notches, fatigue test results for specimens of $(\alpha+\beta)$-titanium alloy Ti-6Al-4V condensate obtained by the EB PVD method [11] were used. EB PVD coatings of the Ti-6Al-4V alloy were prepared by deposition of the same but cast alloy onto flat substrates. Composite workpieces of the condensate/substrate system were fabricated in the same manner. During deposition, some big droplets depart from the surface of the melt, settling in the condensate and forming columns, which grow and reach the condensate surface. These columns are efficient surface stress concentrators and adversely affect on the fatigue resistance characteristics of the Ti-6Al-4V alloy condensate [11]. The investigation of specimen fatigue fracture surfaces revealed that for almost all but three specimens, crack initiation occurred within the concentrator on the condensate surface. In three specimens, fatigue cracks were initiated on the substrate surface. Therefore, the latters were considered to be such that represent a relatively defect-free condensate, or, in other words, to be "smooth" specimens. The most typical fatigue fracture surfaces are shown in Fig. 1.

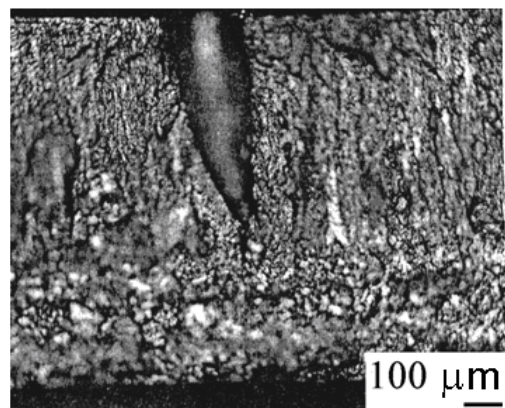

a

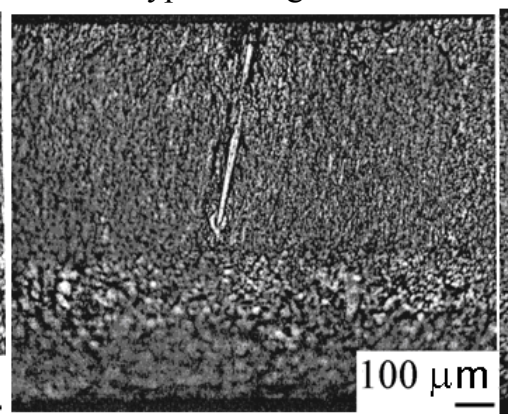

$b$

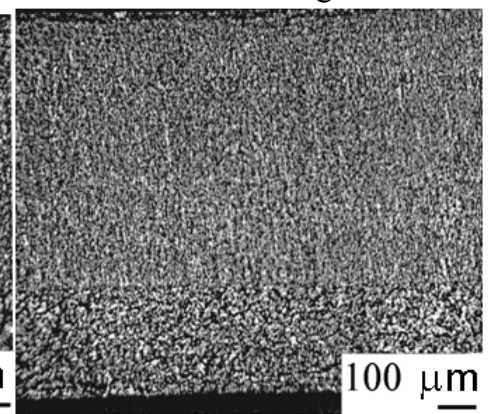

$c$

Fig. 1. Typical fatigue fracture surfaces of specimens: (a) fracture from the notch $(2 \rho \cong 200 \mu \mathrm{m})$; $(b)$ fracture from the notch ( $2 \rho \cong 20 \mu \mathrm{m}) ;(c)$ fracture was initiated on the side of the substrate

To perform the fatigue life estimation of specimens of the Ti-6Al-4V alloy condensate, we used the following basic data: $E=1.25 \cdot 10^{5} \mathrm{MPa}, v=0.3, \sigma_{p}=820 \mathrm{MPa}, d=3.5 \mu \mathrm{m}$ [11]. From the crystallographic texture analysis of the condensate [11] it was concluded that under cyclic loading, the slip and fatigue crack initiation, took place in the prismatic planes of close-packed hexagonal (c.p.h.) crystals of the titanium $\alpha$-phase. Therefore, it is assumed that $b=2.5 \cdot 10^{-10} \mathrm{~m}$ and $h=b \sqrt{3}=4.33 \cdot 10^{-10} \mathrm{~m} \mathrm{[3]}$. Based on the above crystallographic orientation of $\alpha$-grains and also taking into account that every $\alpha$-crystal has three slip directions in the prismatic planes, it may be concluded that a grain $(d=3.5 \mu \mathrm{m})$ with the orientation most favorable for slip will always be found on the specimen surface along the perimeter of notches under study $(2 \rho=20 \ldots 300 \mu \mathrm{m})$. Thus, $M$ is assumed to be equal to 2, i.e., the lowest value of this parameter. The theoretical stress concentration factors $K_{t}$ for each tested specimen with a notch of an appropriate diameter $2 \rho$ were calculated by finite element method (FEM). In this case, the notch, or stress concentrator, was simulated by a through hole located at the center of the region $200 \mathrm{~mm}$ in length, $10 \mathrm{~mm}$ in width and $1 \mathrm{~mm}$ in thickness. 
Figure 2 illustrates the elastic distributions of local stresses from the concentrator tip in the direction perpendicular to $\sigma_{a}=\sigma_{-1}$ for different arbitrary concentrator diameters on the specimen surface. Here, $\sigma_{-1}$ for each concentrator diameter $2 \rho$ was calculated by formula (20). The horizontal line corresponds to $\sigma_{-1, e}$ of a smooth specimen, i.e., it is calculated by formula (20) for $K_{t}=1$ and $\rho=\infty$. The arithmetic mean of the abscissas of intersection of the corresponding local distribution curves with the horizontal $\sigma_{a}=\sigma_{-1, e},\left(l_{c}^{*}\right)_{m}$, equal to $13.72 \mu \mathrm{m}$, is in good agreement with $l_{c}=13.8 \mu \mathrm{m}$ determined by formula (5), which confirms the validity of the above assumption about the identity of these critical distance parameters. Ideally, the local stress distribution curves for different $\rho$ and the horizontal $\sigma_{a}=\sigma_{-1, e}$ (that is, for $\rho=\infty$ ) must intersect at one point. However, as evidenced in Fig. 2, this is not observed in reality, since the distribution curves are obtained purely theoretically, whereas the fatigue limits are calculated from equation (20) in view of (5), which are of an empirical nature.
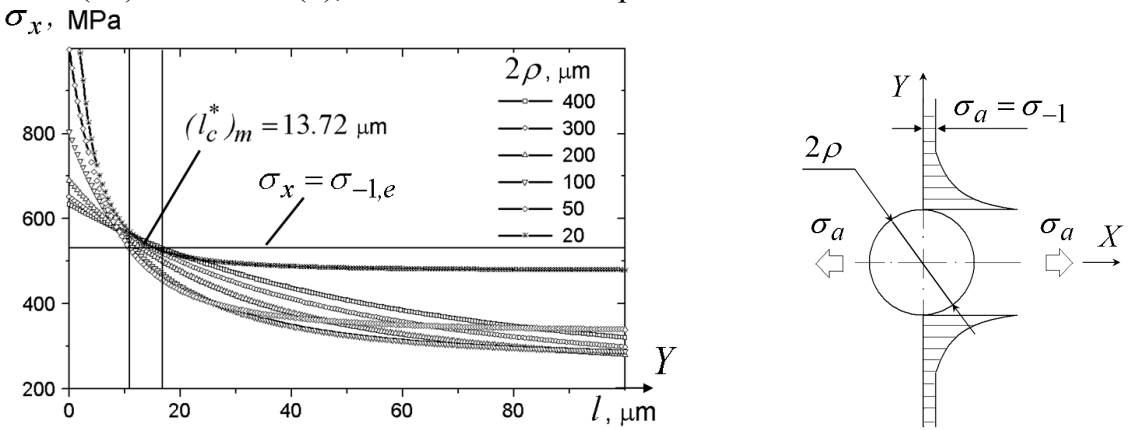

Fig. 2. FEM analysis of elastic distributions of local stresses at the concentrator tip

Fig. $3 a$ depicts the results of fatigue tests performed according to the specified criterion $l_{t}=0.1 \mathrm{~mm}$ for alloy Ti$6 \mathrm{Al}-4 \mathrm{~V}$ composite (condensate-substrate) specimens, in nominal stress amplitude, $\sigma_{a}$ vs. number of load cycles, $N$, coordinates. The $S$ - $N$ curves calculated by the proposed model for the defect-free condensate (curve 1) and condensate with the largest stress concentrator (curve 2) are plotted in this same figure. As seen from Fig. $3 a$, practically all the experimental points (open circles) representing specimens with defects of various sizes lie in the region bounded by these curves. Solid square symbols represent specimens in which the fracture started on the side of the substrate, which is indicative of a higher fatigue strength of the defect-free condensate as compared to the substrate. Therefore, the fact that these points lie slightly below the calculated curve 1 is fully justified.

A comparison between the calculated and experimental lives for each tested specimen is shown in Fig. $3 b$, where a good agreement between the calculated and experimental data is seen.
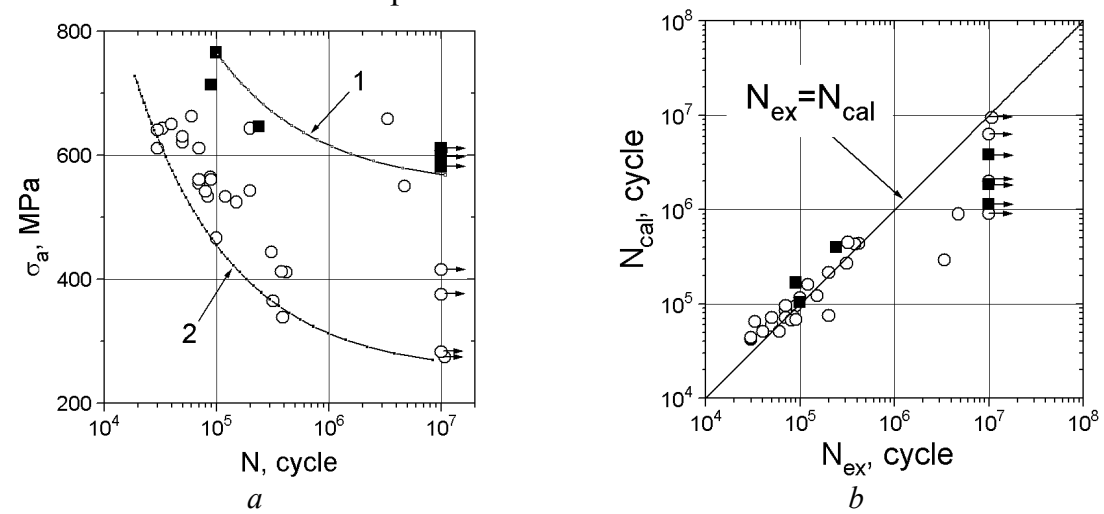

Fig. 3. Comparison between the calculated and experimental results. (a) calculated fatigue curves: curve 1 for the defect-free condensate $\left(\rho=\infty, K_{t}=1\right)$, curve 2 for the condensate with a concentrator in the form of a through hole of diameter

$2 \rho=300 \mu \mathrm{m}\left(K_{t}=2.913\right) ;(\boldsymbol{b})$ comparison between the calculated $N_{c a l}$ and the experimental lives $N_{e x} \cdot \circ$, a correspond to the experimental data; $\bigcirc$ denotes the fracture initiated from the defect in the condensate, $\square$ denotes the fracture initiated from the substrate surface. Symbols with arrows correspond to unbroken specimens

Cycle stress ratio. To perform fatigue life estimation in the case of asymmetrical loading cycle, it is proposed to use the same approach as for the case with the notch. That is, the cycle stress ratio effect is taken into account in the equation for fatigue life to crack initiation in terms of the effect of applied mean-stress on the fatigue limit. At present, the fatigue strength for the asymmetrical cycle of loading is defined by the stress range, $\Delta \sigma_{R}$, or by the maximum 
cycle stress, $\sigma_{\max , R}$, as the empirical power function of the fatigue limit for a fully-reversed loading cycle and the applied mean stress, as follows [12]:

$$
\Delta \sigma_{R}=\Delta \sigma_{-1}\left(1-\left(\sigma_{m} / \sigma_{L}\right)^{n}\right),
$$

where $\sigma_{m}$ is the applied mean stress, $\sigma_{L}$ is the fatigue limiting condition (either yield stress, $\sigma_{0.2}$, or ultimate tensile strength, $\left.\sigma_{U T S}\right)$, (i.e., the design criterion shifts from fatigue to yielding or to fracture when the limiting or critical condition is reached), and $n$ is the exponent 1 or 2 , indicating how fast/slow the fatigue limiting condition is reached. For titanium alloys, it is assumed that $n=1$ and $\sigma_{L}=\sigma_{0.2}$. Then, in view of $\Delta \sigma_{-1}=2 \sigma_{-1}, R=\sigma_{\min } / \sigma_{\max }$ and $\sigma_{m}=\left(\sigma_{\min }+\sigma_{\max }\right) / 2$, the following expression is obtained from (23) for fatigue limit estimation at various cycle stress ratios, $R$,

and

$$
\Delta \sigma_{R}=\frac{2 \sigma_{-1}}{1+\left(\sigma_{-1}(1+R)\right) /\left(\sigma_{0.2}(1-R)\right)}
$$

$$
\sigma_{\max , R}=\Delta \sigma_{R} /(1-R)
$$

Then, the equation for fatigue life to crack initiation taking into account the cycle stress ratio is represented in the following manner:

or

$$
N_{i}=\beta^{2} /\left(\sigma_{\max }-\sigma_{\max , R}\right)^{2}
$$

where $\beta$ is calculated by formula (3).

$$
N_{i}=(1-R)^{2} \beta^{2} /\left(\Delta \sigma-\Delta \sigma_{R}\right)^{2}
$$

At the stage of crack growth, equation (6) is used with no change since the key parameter $l_{s}$ (see equation (8)) defined by the ratio of $\Delta K_{t h}$ to $\Delta \sigma_{R}$ is constant for a certain material and is independent of the stress ratio. It is only needed to substitute $\sigma_{\max , R}$ for $\sigma_{-1}$ and $\sigma_{\max }$ for $\sigma_{a}$ in equations (6) - (17).

To confirm the validity of the above-proposed approach, experimental fatigue testing data of Ti-6Al-4V titanium alloy specimens were used for various cycle stress ratios taken elsewhere from the literature [13]. The following basic data are used in the calculations: $E=1.1 \cdot 10^{5} \mathrm{MPa}, v=0.3, \sigma_{0.2}=915 \mathrm{MPa}, \sigma_{p} \cong 0.75 \cdot \sigma_{0.2}=686 \mathrm{MPa}, d=20 \cdot 10^{-6}$ $\mathrm{m}, M=2.174$ (are taken from [13]), $b=2.5 \cdot 10^{-10} \mathrm{~m}, h=4.5 \cdot 10^{-10} \mathrm{~m}$ (are taken from [3]). Considering that fatigue tests in [13] were carried out on $3 \mathrm{~mm}$ dia. specimens subjected to uniaxial cyclic loading until their complete fracture, the final depth, $l_{t}=2 \mathrm{~mm}$, of a semicircular crack was taken as a fatigue failure criterion on the assumption that $1 \mathrm{~mm}$ is due to the final (instantaneous) rupture of the specimen.

Figure 4 illustrates the comparison of the calculated $S-N$ curves and experimental data in coordinates: $\sigma_{\max }$ vs. $N_{\text {total }}$ (left) and $\Delta \sigma$ vs. $N_{\text {total }}$ (right). As seen, there is a good agreement between the calculated curves and experimental data, which thus confirms the validity of the proposed approach. However, some experimental data representing fatigue fracture results for a relatively high applied stress, $\sigma_{\max }>\sigma_{0.2}$, show the fatigue life values one order of magnitude lower than the calculated ones. This indicates that the proposed model can be used only for HCF conditions, i.e when the applied stress, $\sigma_{\max }$, is within the elastic region of the static stress-strain curve.

In the case when the both factors, i.e., the stress concentration and cycle stress ratio, are present, it is only needed to substitute equation (20) for $\sigma_{-1}$ in (24), and to calculate the fatigue life to crack initiation using equation (26) or (27).
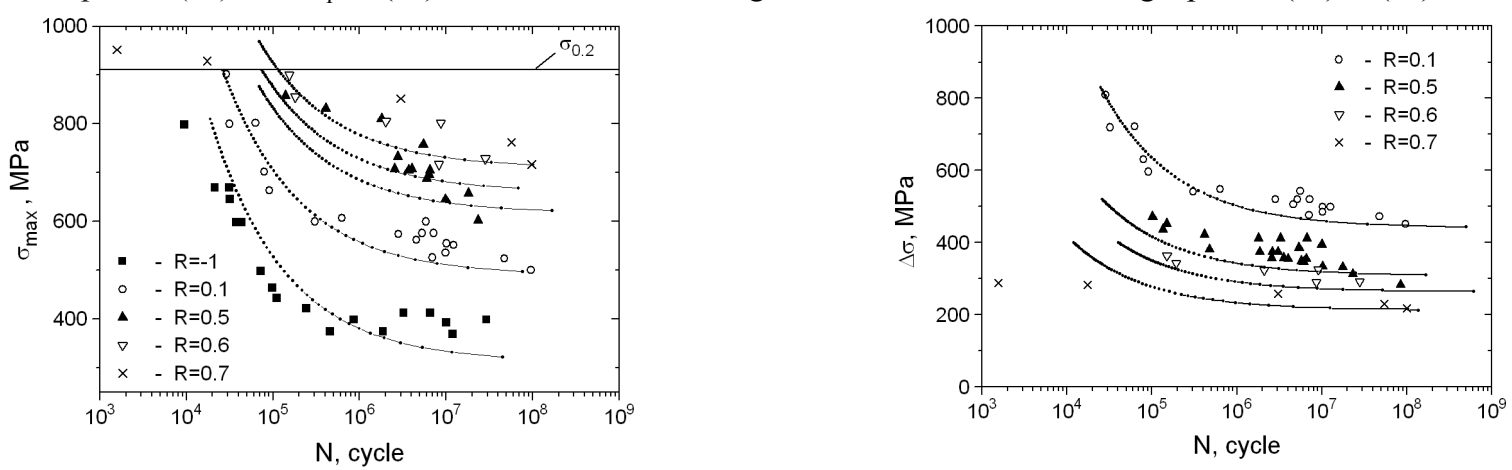

Fig. 4. Comparison between the calculated fatigue curves and experimental fatigue data of titanium alloy Ti-6Al-4V for various $R$. Experimental data were taken from [13] 


\title{
Conclusions
}

1. The approach proposed can be used for the rapid assessment of fatigue resistance characteristics in new materials development, and also for the remaining life evaluation of structures with no costly and long-term fatigue and fatigue crack growth resistance tests.

2. To fill the model proposed, it is necessary to determine the elasticity characteristics, such as elastic modulus, $E$, Poisson's ratio, $v$, the proportional limit, $\sigma_{p}$, and the yield stress, $\sigma_{0.2}$, from monotonic tensile tests of standard specimens of the alloy under study, and also the mean grain size, $d$, mean value of the Taylor factor, $M$, the magnitude of the Burgers vector, $b$, the distance between neighboring parallel slip planes in the lattice, depending on which slip system is activated relative to the tension direction, $h$, from the analysis of microstructure and texture of the initial material. The theoretical stress concentration factor, $K_{t}$, for the corresponding radius $\rho$ at the notch tip needs to be calculated using FEM or simplified proper formulas taken from handbooks.

3. The model proposed for calculating the fatigue life to crack initiation is applicable for:

- the high-cycle fatigue region under regular cyclic uniaxial loading;

- $\quad$ planar slip metals and alloys;

- $\quad$ shallow and blunt stress concentrators $\left(K_{t}<4\right)$;

- $\quad$ crack nucleation on the surface of a material.

4. In the calculation of fatigue life to crack initiation, the factors, such as grain size, stress concentration and cyclic load ratio, are taken into account by the parameter representing the fatigue limit.

\section{Теоретична оцінка втомної довговічності за регулярного циклічного навантаження}

\section{Олег Герасимчук, Олена Герасимчук}

\begin{abstract}
Анотація. Запропоновано модель для оцінки втомної довговічності матеріалу з урахуванням мікроструктури, концентрації напружень $і$ асиметрії циклу навантаження. Модель апробовано на результатах втомних випробувань зразків із конденсату титанового сплаву Ti-6Al-4V, отриманого методом електронно-променевого осадження у вакуумі з парової фазы (ЕВ PVD- метод). Зразки мали технологічні дефекти у вигляді колон різного діаметра, які виходили на поверхню зразка. Модель також перевірено на експериментальних втомних даних сплаву Ti-6Al-4V, взятих з літератури, для різних асиметрій циклу навантаження. Порівняння результатів розрахунку й експерименту показало задовільний збіг. Для наповнення моделі достатньо мати результати випробувань на короткочасний розтяг та характеристики мікроструктури вихідного матеріалу. Запропонований підхід може бути використаний для експрес-оцінки характеристик опору втомному руйнуванню на етапі розробки нових матеріалів, а також для оцінки залишкового ресурсу елементів конструкиій, без застосування коштовних і довготривалих випробувань на втому та втомну тріщиностійкість.
\end{abstract}

Ключові слова: втомна довговічність; конщентрація напружень; асиметрія ичиклу; багатоииклова втома; мікроструктура; титанові сплави

\section{Теоретическая оценка усталостной долговечности при регулярном циклическом нагружении}

\author{
Олег Герасимчук, Елена Герасимчук
}

\begin{abstract}
Аннотация. Предложена модель для оценки усталостной долговечности материала с учетом микроструктуры, концентрации напряжений и асиметрии иикла нагружения. Модель апробирована на результатах усталостных испытаний образцов из конденсата титанового сплава Ti-6Al-4V, полученного методом электронно-лучевого осаждения 6 вакууме из паровой фазы (ЕВ PVD- метод). Образиь имели технологические дефекты в виде колонн разного диаметра, которые выходили на поверхность образиа. Модель также проверена на экспериментальных усталостных данных сплава Ti-6Al-4V, взятых из литературы, для различных асимметрий иикла нагружения. Сравнение результатов расчета и эксперимента показало удовлетворительное совпадение. Для наполнения модели достаточно иметь результать испытаний на кратковременное растяжение и характеристики микроструктуры исходного материала. Предложенный подход может быть использован для экспресс-оценки характеристик сопротивления усталостному разрушению на этапе разработки новых материалов, а также для оиенки остаточного ресурса элементов конструкций без применения дорогостоящих и длительных испытаний на усталость и усталостную трещиностойкость.
\end{abstract}

Ключевые слова: усталостная долговечность; концеентрация напряжений; асимметрия цчикла; многоцикловая усталость; микроструктура; титановые сплавы 


\section{References}

1. Herasymchuk, O.M., Kononuchenko, O.V., Markovsky, P.E. and Bondarchuk, V.I. (2016), "Calculating the fatigue life of smooth specimens of two-phase titanium alloys subject to symmetric uniaxial cyclic load of constant amplitude", Int. J. Fatigue, No. 83, pp. 313-322, DOI: 10.1016/j.ijfatigue.2015.11.002

2. Herasymchuk, O.M. (2011), "Nonlinear relationship between the fatigue limit and quantitative parameters of material microstructure", Int. J. Fatigue, No. 33, pp. 649-659.

3. Herasymchuk, O.M. (2015), "Microstructurally-dependent model for predicting the kinetics of physically small and long fatigue crack growth", Int. J. Fatigue, No. 81, pp. 148-161.

4. Lukas, P. and Klesnil, M. (1978), "Fatigue limit of notched bodies”, Mater. Sci. Eng., No. 34, pp. 61-66.

5. El Haddad, M.H., Topper, T.H. and, Smith, K.N. (1979), "Prediction of non propagating cracks", Engineering Fracture Mechanics, No. 11(3), pp. 573-584, DOI: 10.1016/0013-7944(79)90081-X

6. Ostash, O.P., Panasyuk, V.V. (2001), "Fatigue process zone at notches”, Int. J. Fatigue, No23, pp.627-636.

7. Frost, N.E. and Dugdale, D.S. (1957), "Fatigue tests on notched mild steel plates with measurements of fatigue cracks", $J$. Mechs Phys Solids., No. 5, pp. 182-190.

8. Chapetti, M.D. (2003), "Fatigue propagation threshold of short cracks under constant amplitude loading", International Journal of Fatigue, No. 25, pp. 1319-1326, DOI:10.1016/S0142-1123(03)00065-3

9. Dowling, N.E. (1999), Mechanical behavior of materials: engineering methods for deformation fracture and fatigue, 2nd (ed.), Upper Saddle River, Prentice Hall, NJ.

10. Chan, K.S. (2003), “A microstructure - based fatigue - crack - initiation model”, Metall. Mater. Trans. A., No. 34A, pp. 4358, DOI: $10.1007 / \mathrm{S} 11661-003-0207-9$

11. Herasymchuk, O.M., Sergienko, G.A., Bondarchuk, V.I., Terukov, A.V., Nalimov, Yu.S. and Gryaznov, B.A. (2006), "Fatigue strength of an $(\alpha+\beta)$-type titanium alloy Ti-6Al-4V produced by the electron-beam physical vapor deposition method", Strength of Materials, No. 38(6), pp. 651-658.

12. Sadananda, K., Sarkar, S., Kujawski, D. and Vasudevan, A.K. (2009), "A two-parameter analysis of S-N fatigue life using $\Delta \sigma$ and $\sigma_{\max } "$, Int. J. Fatigue, No. 31, pp. 1648-1659, DOI: 10.1016/j.ijfatigue.2009.03.007

13. Peters, J.O., Boyce, B.L., Chen, X., McNaney, J.M., Hutchinson, J.W. and Ritchie, R.O. (2002), "On the application of the Kitagawa-Takahashi diagram to foreign-object damage and high-cycle fatigue", Engineering Fracture Mechanics, No. 69, pp. $1425-1446$. 